\title{
Social support for patients with spinal cord injuries - The case of the Clinical Rehabilitation of the University of Patras
}

\author{
Mentis', M., Kyriakidis', A., Tzanos ${ }^{1}$, A.,Panagiotopoulos'1, E. \\ 1. Spinal Cord Injury Clinic, University of Patras
}

Berkman (1986) and Cassel (1976) have shown that individuals who have join organized social networks face better pain situations, and there are a number of studies that show the positive link between social support and social networks with good physical and mental health.

Objectives: The purpose of the study was to investigate social support in patients with spinal cord injuries hospitalized in Patient's Spinal Cord Injury Rehabilitation Clinic in 2014-2018.

Materials and methods: The study was retrospective and was based on a sample of 30 patients who were hospitalized at the University Clinic for the Recovery of Spinal Cord Injuries during the 2014-2018 period and met the criteria for participation in the research. The measurement of social support was made with Short Form Social Support Questionnaire (SSQ6), which measures the social network size (SSQ1) and the perceived satisfaction (SSQ2). The credibility of internal consistency was found to be satisfactory (for SSQ1 Cronbach's $\alpha=0,787$ and for SSQ2 Cronbach's $\alpha=0,783$ ).

Results: $83 \%$ of the sample were paraplegic and $17 \%$ were tetraplegic. The majority of the sample was $83.3 \%$ of secondary school graduates and only $17 \%$ were university graduates. People with paraplegia had an average disability of 12 years and those with quadriplegia of 15.4 years. Comparison between groups (paraplegic and quadriplegic) showed no significant difference in demographic characteristics. The only statistical difference observed was in systolic pressure $(p<, 05)$, as it was observed that paraplegics had higher values compared to the tetraplegic ones. In terms of social support, the size of the social network was found to be high (20.46 people) and perceived satisfaction with it was high (31.86), values that are higher than the corresponding weights in the general population. Comparison of paraplegic and quadriplegic versus SSQ1 (network size) and SSQ2 (perceived satisfaction) showed that people with paraplegia had higher SSQ1 and SSQ2 than quadriplegic

\begin{tabular}{|c|c|c|c|}
\hline & \multicolumn{2}{|c|}{ Type of disability } & \multirow{2}{*}{$\begin{array}{l}\text { Statistical } \\
\text { significance }\end{array}$} \\
\hline & $\begin{array}{c}\text { Paraplegia } \\
\mathrm{N}=25(( \pm \mathrm{SD})\end{array}$ & $\begin{array}{l}\text { Quadriplegic } \\
N=5(( \pm S D)\end{array}$ & \\
\hline Age & $46.8410 .25)$ & $40.00(12.37)$ & $\begin{array}{l}\mathrm{t}=1.429 \\
\mathrm{p}=.203\end{array}$ \\
\hline $\begin{array}{l}\text { Gender: } \\
\text { Male / Female }\end{array}$ & $22 / 5$ & $3 / 0$ & $\begin{array}{c}\text { Likelihood } \\
\text { Ratio= }=1,159 \\
p=.282\end{array}$ \\
\hline $\begin{array}{l}\text { Education } \\
\text { Secondary } \\
\text { /Higher }\end{array}$ & $20 / 5$ & $5 / 0$ & $\begin{array}{c}\text { Likelihood } \\
\text { Ratio }=2,014 \\
\mathrm{p}=.156\end{array}$ \\
\hline $\begin{array}{l}\text { Employment } \\
\text { Unemployed / } \\
\text { employee } \\
\text { retired }\end{array}$ & $\begin{array}{c}9 \\
4 \\
12\end{array}$ & $\begin{array}{l}3 \\
1 \\
1\end{array}$ & $\begin{array}{c}\text { Fisher's } \\
\text { Exact } \\
\text { Test }=2,418 \\
p=.506\end{array}$ \\
\hline $\begin{array}{ll}\text { Years } & \text { of } \\
\text { disability } & \\
\end{array}$ & $12.00(11,86)$ & $15.4(12,05)$ & $\begin{array}{l}\mathrm{t}=-, 583 \\
\mathrm{p}=.564\end{array}$ \\
\hline Pain intensity & $4,41(2,51)$ & $2,25(2,87)$ & $\begin{array}{l}t=-1,566 \\
p=.129\end{array}$ \\
\hline $\begin{array}{l}\text { Blood pressure } \\
\text { (systolic) }\end{array}$ & $136,77(15,02)$ & $\begin{array}{r}108,50 \\
(19.09) \\
\end{array}$ & $\begin{array}{l}t=2,513 \\
p=.02\end{array}$ \\
\hline $\begin{array}{l}\text { Blood pressure } \\
\text { (diastolic) }\end{array}$ & $81,63(11,21)$ & $(65,50)(7,77)$ & $\begin{array}{l}t=1,971 \\
p=.061\end{array}$ \\
\hline
\end{tabular}

\section{References}

1. Berkman L. F. (1986). "Social networks, support and health: Taking the next step forward" American Journal of Epidemiology, 123 (2):559- 562. individuals, but there was no statistical difference between the two groups. Finally, in relation to the persons who make up the social network, the impression is that although people with spinal cord disabilities have a great need for care, it seems that they receive more social support from their friends and less from their relatives.

Conclusion: The results of the study showed that people with spinal cord injuries receive high social support and in fact the mean values were found to be higher than the weighted average values in the general population. This finding, though paradoxical, as it would be expected that disability, like chronic illness, would have a negative impact on the size of the social network due to disability constraints, especially in Greece, which faces major accessibility problems for people with disabilities as well as at the level of perceived social support, however, the results show a large social network and high satisfaction with social support. One possible explanation for the "paradoxical" results may be in terms of the size of the social network that the sample subjects were heavily involved with in sport (many participating in a wheelchair basketball team), while having offset accessibility problems with their involvement in electronic social networks, as almost everyone has high skills in using technology and the internet (mobile phone, PC). With regard to high satisfaction with social support, one possible interpretation may be that due to severe disability these people have learned to appreciate what they have and are satisfied with that without having excessive expectations. In conclusion, involvement with sport contributes to the greater social networking of people with severe disabilities, and in this sense rehabilitation services and programs should encourage people with paraplegia or quadriplegia to engage in sports.

\begin{tabular}{|l|c|c|c|}
\hline \multirow{2}{*}{ Table 2. Social support for people with spinal cord injuries } \\
\hline \multirow{3}{*}{ SSQ } & $\begin{array}{c}|c| \\
\text { Paraplegia } \\
N=25(( \pm S D)\end{array}$ & $\begin{array}{c}\text { Quadriplegic } \\
N=5(( \pm S D)\end{array}$ & $\begin{array}{c}\text { Statistical } \\
\text { T Test }(p)\end{array}$ \\
\cline { 2 - 3 } SSQ1 & $20,95(11,68)$ & $18,75(12,47)$ & .731 \\
\hline SSQ2 & $32,16(4,84)$ & $30,25(9,60)$ & .532 \\
\hline $\begin{array}{l}\text { Persons who form the social network for the social support of } \\
\text { people with paraplegia or quadriplegia N=30 / Total number of } \\
\text { free references=628 } \%)\end{array}$ & \multicolumn{2}{|c|}{$188(29,9)$} \\
\hline Friends & $117(18,6)$ \\
\hline Brothers & $86(13,7)$ \\
\hline Parents & $69(10,9)$ \\
\hline Wives & $51(8,1)$ \\
\hline Children & $78(12,4)$ \\
\hline Other persons & $11(1,8)$ \\
\hline God / Religion & $6(1,0)$ \\
\hline Pets & $13(2,1)$ \\
\hline No one & $9(1,4)$ \\
\hline Athers & \multicolumn{2}{|c|}{} \\
\hline
\end{tabular}

2.Cassel J. (1976). "The contribution of the social environment to host resistance", American Journal of Epidemiology, 104 (2): 107- 123.

3. World Health Organization. (2013). International Perspectives of Spinal Cord Injury 